\title{
Lake sediments deposited on the Flims rockslide mass: the key to date the largest mass movement of the Alps
}

\author{
Gaudenz Deplazes, ${ }^{1}$ Flavio S. Anselmetti ${ }^{1,2}$ and Irka Hajdas ${ }^{3}$ \\ ${ }^{1}$ Geological Institute, Swiss Federal Institute of Technology ETHZ, CH-8092 Zürich, Switzerland; ${ }^{2}$ Eawag Swiss Federal Institute of Aquatic \\ Science and Technology, CH-8600 Dubendonf, Switzerland; ${ }^{3}$ Institute of Particle Physics, Swiss Federal Institute of Technology ETHZ, \\ Schafmattstr. 20, CH-8093 Zürich, Switzerland
}

\begin{abstract}
Long piston cores taken from the subsurface of two mountain lakes of the eastern Swiss Alps recovered sediments, which overlie the Flims rockslide deposits. These sediments provide new information on the chronology of the largest known Alpine rockslide and can be used to reconstruct the post landslide environmental evolution. The oldest ${ }^{14} \mathrm{C}$ date of the lake sediments yields a minimum age of the rockslide at 9660 9430 cal. yr BP. In addition, the dating of a wood fragment contained in the rockslide deposits directly below the lake
\end{abstract}

sediments shows a maximum age of $9480-9120 \mathrm{cal}$. yr BP. The overlap of the maximum and minimum ages, 9480-9430 cal. yr $\mathrm{BP}$, approximates the age of the Flims rockslide. This early Holocene range coincides with a period of higher frequency of large mass movements observed in the Alps, which could be related to climatic changes.

Terra Nova, 19, 252-258, 2007

\section{Introduction}

Rockslides in mountainous areas act as an important control on morphological landscape evolution and represent a major natural hazard (Bonnard, 2004; Crozier and Glade, 2005). Investigations of large landslides show that their timing and trigger mechanisms include climatic controls, glacial/ deglacial rebound effects and seismic shaking (Blair, 1994; Corsini et al., 2001; Erismann and Abele, 2001; Schmidt and Beyer, 2002; Schnellmann et al., 2002). The Flims rockslide in the Vorderrhein Valley, Eastern Switzerland, is the largest known mass movement in the Alps. This event is estimated to have mobilized $\sim 8-11 \mathrm{~km}^{3}$ of limestone that covers an area of $\sim 52 \mathrm{~km}^{2}$ (Heim, 1932; Abele, 1974; Poschinger et al., 2006) (Fig. 1). The rockslide dammed the valley and produced the so-called Ilanz Lake, which later drained through the Rhine gorge cutting through the rockslide mass. The estimation of the maximum water level of this lake varies from $936 \mathrm{~m}$ a.s.l. (Poschinger, 2005 ) to $\sim 1100 \mathrm{~m}$ a.s.l. (Schneider et al., 2004). The erosional cut into the up to $600 \mathrm{~m}$ high rockslide mass provides spectacular exposures of the internal structure of these deposits.

Correspondence: G. Deplazes, Tollwiesstr. 29, CH-8700, Küsnacht, Switzerland. Tel.: + 4144910 4575; e-mail: gaudenz. deplazes@alumni.ethz.ch
Many investigations of the Flims rockslide have documented slide processes, making it a text book example (Schneider et al., 1999; Pollet and Schneider, 2004; Pollet et al., 2005).

The Flims rockslide has been attributed to the Late Glacial period, based mostly on regional geomorphological evidence and the erratica and morainic material found on top of the rockslide mass (Heim, 1932; Nabholz, 1987; Abele, 1997). The proposed Late Glacial timing for the rockslide suggests that the rebound of the valley flank after the main retreat of the ice masses led to the instability and ultimately caused the rockslide. Recent studies, however, indicate that the rockslide occurred more probably in the early Holocene. Wood fragments, which were mobilized and redeposited with the debris, were sampled from the base of the distal rockslide deposit in the Versam Gorge, and have been dated with radiocarbon methods (Poschinger and Haas, 1997; Schneider et al., 2004). Their ages range between 9250 and 9500 cal. yr BP and represent maximal ages of the rockslide. Furthermore, Schneider et al. (2004) proposed that the outbreak of the Ilanz Lake produced a major flood, which resulted in two closely spaced clastic layers in downstream Lake Constance. These layers have been dated as $\sim 9400$ cal. yr BP with lithologic correlations to other dated sediment cores (Wessels, 1998). Surface exposure dating of boulder and bedrock surfaces with cosmogenic 36 $\mathrm{CL}$ and $10 \mathrm{Be}$ also point to an early Holocene age (Ivy-Ochs et al., 2007).

To provide new and independent age information and to reconstruct the post-rockslide regional evolution, this study investigated lacustrine sedimentation in two small mountain lakes (Lag la Cauma and Lag Grond) that were nucleated in topographic depressions on the slide masses after the emplacement of the rockslide debris. As lacustrine sedimentation began after the slide event, a complete lacustrine chronological sequence starting with the oldest sediments can provide a minimum age of the rockslide. In addition to the minimum age, any datable material deposited within the rockslide beneath the lake sediment will complete the chronological sequence and, thus, narrow the potential age window of the Flims event.

\section{Methods}

The sedimentary subsurface of Lag la Cauma and Lag Grond were investigated with a high-resolution reflection seismic survey and a gravity short coring campaign in July 2003. Total sediment thicknesses could not be determined seismically because the seismic signal ( $3.5 \mathrm{kHz}$ Pinger source) could not penetrate the sediments, probably due to the high gas content of the sediments. The lake floor reflection was used to generate bathymetric 


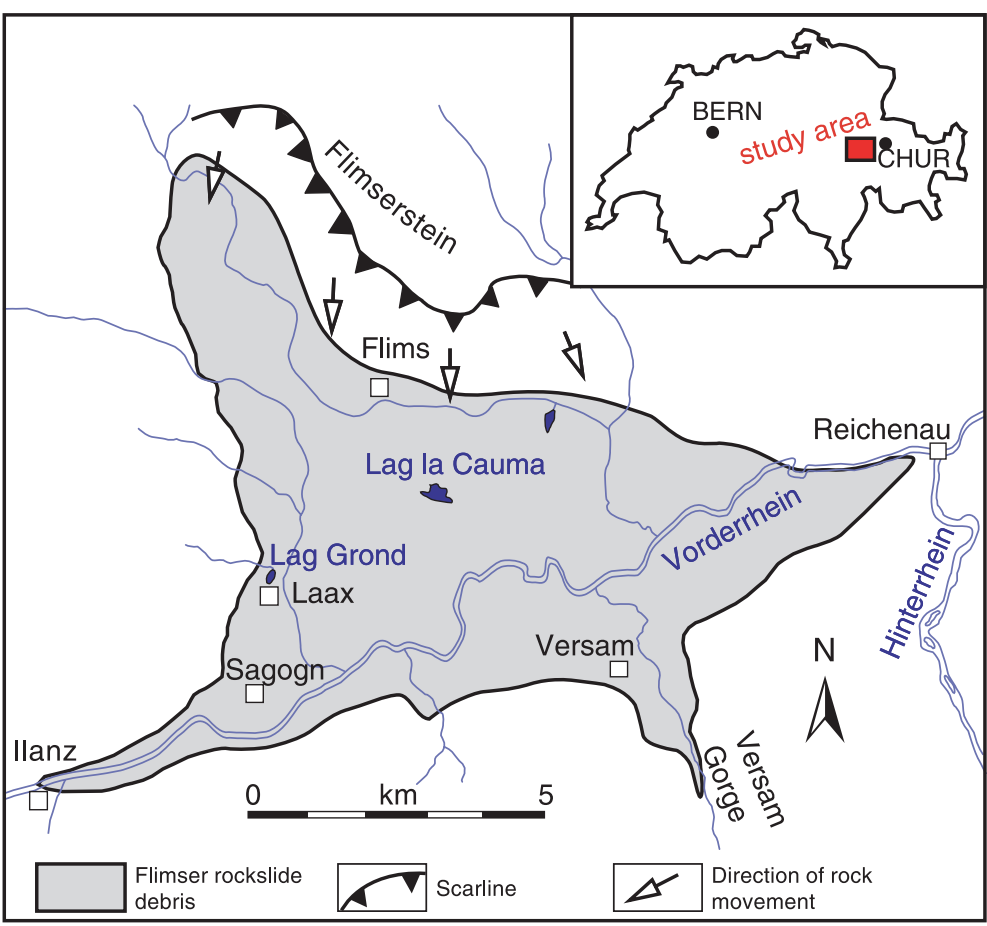

Fig. 1 Map of the rockslide area around Flims in Eastern Switzerland (modified after Bonanomi et al., 1994 and references therein) showing the locations of the investigated lakes.

maps (Fig. 2) and to select the coring sites. Long percussion piston cores were retrieved from Lag la Cauma (May 2004, from a raft) and Lag Grond (February 2005, from the frozen surface). In both lakes, the coring device was hammered into the sediment until a very hard substrate was reached. Gamma-ray attenuation bulk density of the cored lithologies were determined with a multi-sensor core logger at $0.5 \mathrm{~cm}$ resolution. The cores were opened, photographed and sedimentologically described. Organic and inorganic carbon contents were measured coulometrically. Long and short cores were combined to composite sections on the basis of visual core descriptions and petrophysical properties. In order to avoid a hard water effect, remains of terrestrial plants (wood, leaves and needles) only were used for ${ }^{14} \mathrm{C}$ dating. Pretreatment of the samples and graphitization were carried out in two laboratories at the University of Zürich and ETH Zürich (Hajdas et al., 2004). ${ }^{14} \mathrm{C}$ analyses on terrestrial organic matter were made at the AMS Radiocarbon Laboratory at the ETH/PSI facility at Hönggerberg, Zürich (Bonani et al., 1987). The ${ }^{14} \mathrm{C}$ ages were calculated following the convention of Stuiver and Polach (1977) and calibrated ( $2 \sigma$ range) using the OxCal calibration program (version 3.10, Bronk Ramsey, 1995, 1998 , 2001) with INTCAL04 data set (Reimer et al., 2004).

\section{Study sites}

\section{Lag la Cauma}

Lag la Cauma is situated in the middle of the rockslide deposits (Fig. 1) at a mean elevation of $\sim 996 \mathrm{~m}$ a.s.l. It has only a subsurface inflow and outflow, which results in very clear and clean

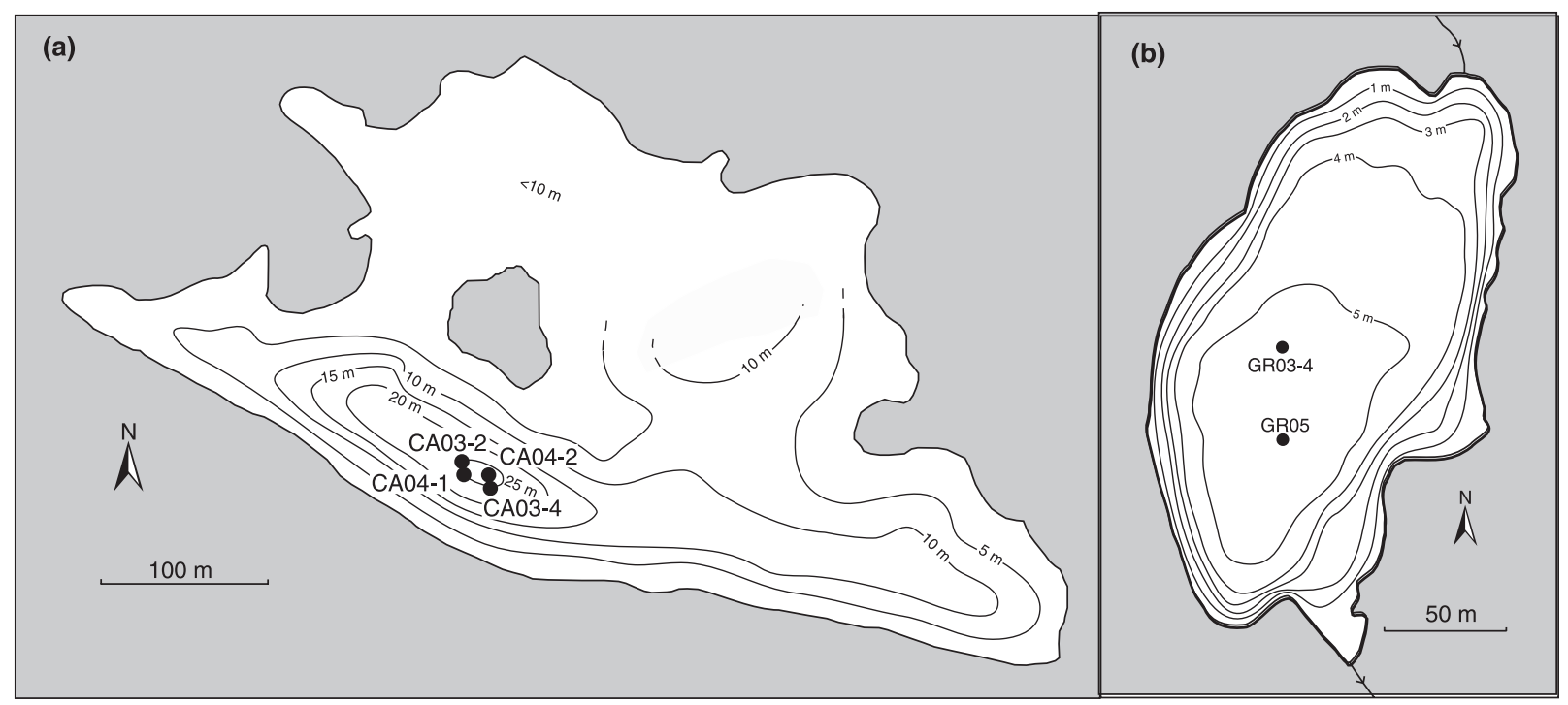

Fig. 2 Bathymetric maps of the two investigated lakes (a) Lag la Cauma (isobaths: $5 \mathrm{~m}$ ) and (b) Lag Grond (isobaths: 1 m) with locations of the coring sites in the deepest part of the basins. The seismic survey in Lag la Cauma was carried out on $22 / 23$ July 2003, with a reference lake level of $\sim 997 \mathrm{~m}$ a.s.l. The lake level of Lag Grond remains constant at $\sim 1016 \mathrm{~m}$ a.s.l. 
water quality. The catchment area is dominated by limestones of the slide debris. Water level oscillates annually by up to $6 \mathrm{~m}$ as a result of snowmelt, precipitation and infiltration time, with maximum water depth of 25 $30 \mathrm{~m}$ usually reached in early summer (Bonanomi et al., 1994). Two long cores taken from the deepest area in Lag la Cauma reached a hard substrate, beyond which no further penetration could be made. At the base of one of these cores, a piece of gravelsized limestone was recovered, supporting the assumption that the hard surface represents the top of the rockslide mass.

The composite section of Lag la Cauma has a length of $\sim 3.9 \mathrm{~m}$. Some differences in sedimentary thickness
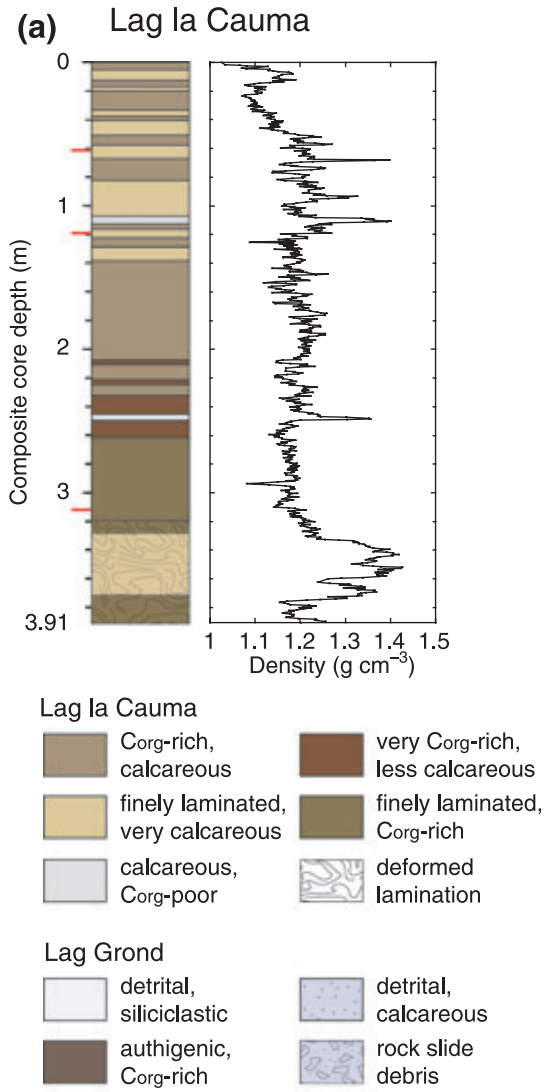

- Composite Section Breaks and in the stratigraphic record between the two cores can be explained with changing current patterns of the subsurface inflows causing partial erosional features. The lowermost section between 3.2 and $3.9 \mathrm{~m}$ displays some deformation likely caused by the percussion piston corer. Sediments consist mainly of calcareous, organic-rich sediments with a minor siliciclastic fraction (Fig. 3A). The sediments show partly very thinly-laminated $(<0.2 \mathrm{~mm})$ rhythmites that are composed of black organic carbon-rich horizons that contrast sharply with the light-coloured, carbonate-rich layers. Most of the carbonate is of authigenic origin as confirmed with crystal morphologies seen in smear slides. Thicker laminated to homogen-

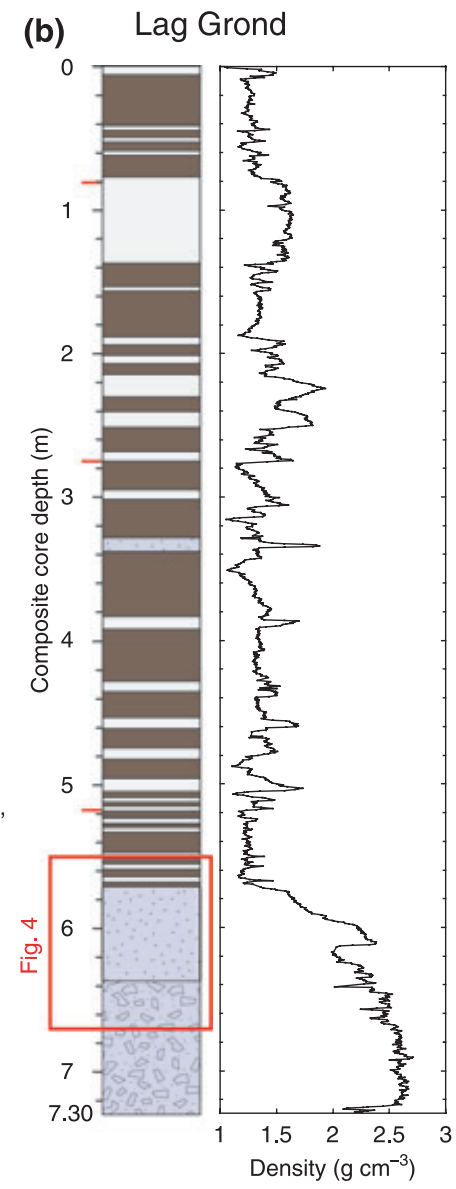

Fig. 3 Comparison of simplified lithology and sedimentary texture with bulk density $\left(\mathrm{g} \mathrm{cm}^{-3}\right)$ of the composite sections from (a) Lag la Cauma and (b) Lag Grond. Lows in bulk density coinciding with visible large voids in the core and at section breaks were removed. Four and five different lithotypes have been distinguished in the sedimentary record for Lag la Cauma and Lag Grond respectively. Density peaks are correlated with high siliciclastic or high calcareous/low organic carbon contents of the sediment. ous sediments with variable amounts of organic matter and carbonates occur as well. Several sections below $\sim 2 \mathrm{~m}$ depth are very rich in organic detritus (needles, leaves and wood fragments; Fig. 3A).

\section{Lag Grond}

Lag Grond is located on the western part of the rockslide debris at an altitude of $1016 \mathrm{~m}$ a.s.1. (Fig. 1). It has a surficial outflow and inflow, and, unlike Lag la Cauma, it is characterized by a dominantly detrital siliciclastic input. During winter, the lake's surface freezes totally. It has a simple bowl-shaped bathymetry with a maximum water depth of $\sim 5.5 \mathrm{~m}$ (Fig. 2). One long core was recovered in the southern part of the lake.

The upper $5.7 \mathrm{~m}$ of the total $7.3 \mathrm{~m}$ long composite section consists mainly of brown sediments (Fig. 3B), which are composed of authigenic carbonate and organic material mixed with the fluvial influx of siliciclastic and organic detritus. The brown sediments are often interrupted by light grey, predominantly siliciclastic layers containing less than $5 \%$ carbonate. The uppermost of these layers from 0 to $5 \mathrm{~cm}$ can be related to a flood event after a 3-day period of extraordinary intense rainfall in November 2002, indicating that these layers represent periods of intense erosion in the siliciclastic-dominated catchment area. Only one of these light-coloured clastic layers, a 3-cm-thick layer at $332 \mathrm{~cm}$ depth is composed of $\sim 80 \%$ detrital carbonate and, thus, sharply contrasts the other flood event layers (Fig. 3B). As very little carbonate rocks outcrop in the catchment area, it is possible that this layer is composed of the reworked products of an additional mass movement from an adjacent catchment that mobilized limestone bedrock or limestone-rockslide breccia.

The section below a sediment depth of $5.7 \mathrm{~m}$ is almost purely composed of limestone clasts (Fig. 4). The top of this interval is characterized by several graded sequences of silt- to gravelsized limestone grains that probably originated from redeposition of rockslide material through turbiditic flow events in an early lacustrine environment. Between the graded 


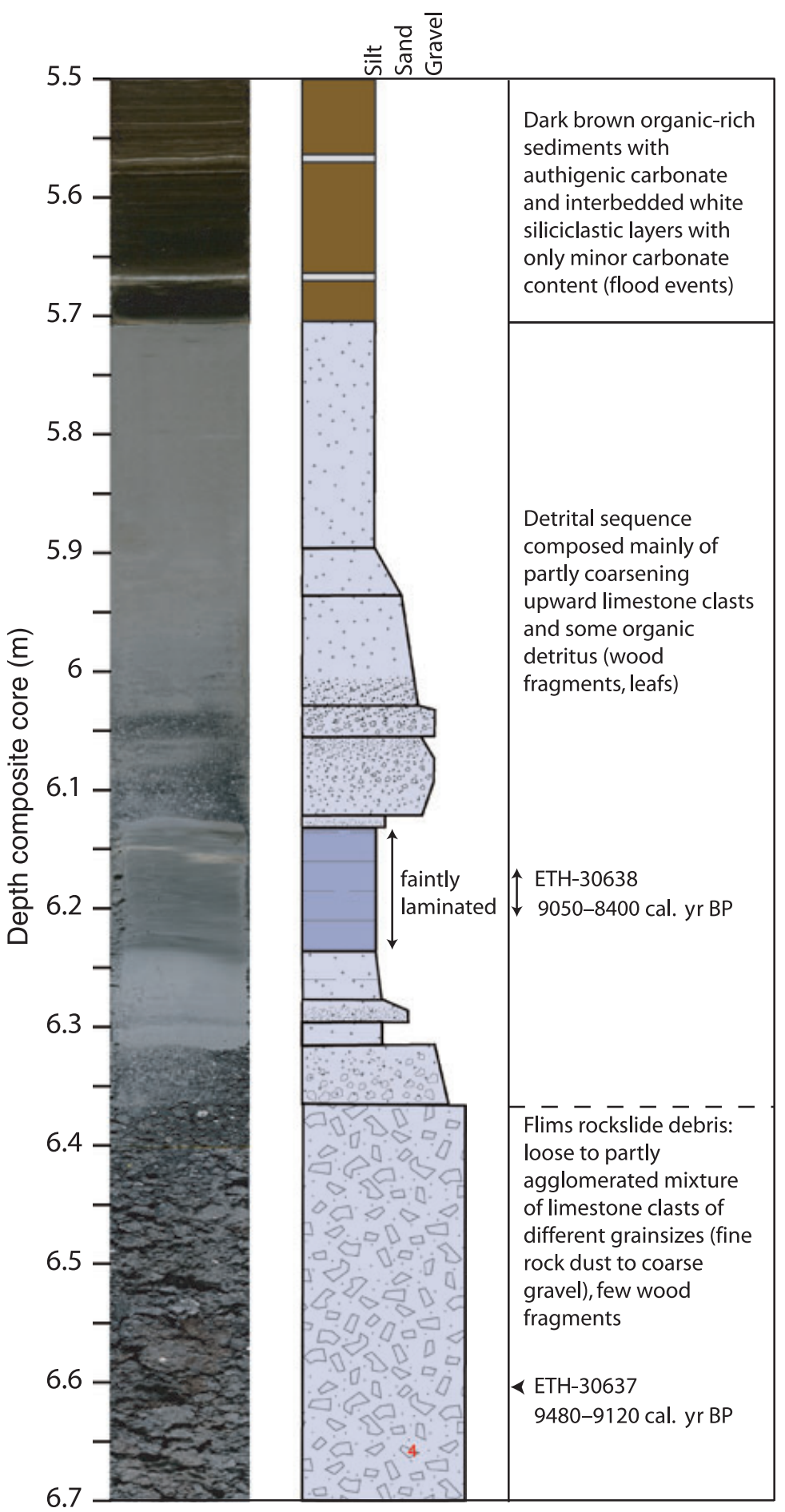

Fig. 4 Detailed lithology and grain size changes in a sediment depth of 5.5-6.7 m of the composite section from Lag Grond (designated by red rectangle in Fig. 3B). The core photograph is horizontally stretched by a factor of 2 . Note the lithologic contrast between the chaotic unsorted breccia below $6.37 \mathrm{~m}$, interpreted to be rockslide material, and the overlying graded, partly laminated sediment interpreted to be deposited in the lacustrine environment.

sequences, a 10-cm-thick, faintly laminated interval occurs, which may indicate a longer period of back- ground sedimentation. The lowest part of the core comprises unsorted and brecciated sediments with an agglomerated texture, as it is known from Rhine gorge outcrops (Pollet and Schneider, 2004). Thus, the lowermost core section most likely represents the Flims rockslide mass, but it can not be excluded that this rockslide material was reworked after the event.

\section{Age models}

Seven samples of terrestrial wood and leaf fragments taken from different sediment depths of the cores from Lag la Cauma have been analysed using ${ }^{14} \mathrm{C}$ dating methods (Table 1). The ${ }^{14} \mathrm{C}$-data provide a consistent downcore age trend (Fig. 5). The oldest dated leaves taken $2.5 \mathrm{~cm}$ above the bottom of the core have a ${ }^{14} \mathrm{C}$ age of $8540 \pm 65$ BP (9660-9430 cal. yr BP). The average sedimention rates amounts to $\sim 0.4 \mathrm{~mm}_{\text {year }}{ }^{-1}$ documenting the slow sedimentation processes in the oligotrophic Lag la Cauma.

Two samples of detrital organic material from Lag Grond have been investigated with ${ }^{14} \mathrm{C}$ dating methods (Fig. 4). Organic material from the $\sim 10$-cm-thick, faintly laminated layer between the graded sequences has a ${ }^{14} \mathrm{C}$ age of $7900 \pm 120 \mathrm{BP}(9050-$ 8400 cal. yr BP). This age results in an average sedimentation rate of $\sim 0.7$ and $0.55 \mathrm{~mm} \mathrm{year}^{-1}$, including and excluding a total of $1.4 \mathrm{~m}$ flood events respectively. A large wood fragment deposited between gravel-sized limestone clasts of the rockslide mass in the lower part of the Lag Grond composite section revealed a ${ }^{14} \mathrm{C}$ age of $8320 \pm 65$ BP $\quad(9480-9120$ cal. yr BP).

The combination of the two age models reveals a refined age window for dating the Flims rockslide (Fig. 5). The oldest age of the Lag la Cauma lacustrine sediment sequence provides a minimum age of the rockslide, reflecting the onset of lacustrine sedimentation after the event (9660-9430 cal. yr BP). Furthermore, the dating of the wood fragment in the rockslide material below Lag Grond yields the maximum age (9480-9120 cal. yr BP). The minimum and maximum calendar ages theoretically overlap between 9480 and 9430 cal. yr BP, yielding a time window that approximates the age of the Flims rockslide. The early 
Table 1 Radiocarbon ages obtained on organic material from sediment cores taken from Lag la Cauma (CA) and Lag Grond (GR), Switzerland.

\begin{tabular}{llllllll}
\hline Core & $\begin{array}{l}\text { Section } \\
\text { depth }(\mathbf{c m})\end{array}$ & $\begin{array}{l}\text { Composite } \\
\text { depth }(\mathbf{c m})\end{array}$ & Material & $\begin{array}{l}\text { C14 age } \\
(\mathbf{y r} \text { BP) }\end{array}$ & ${ }^{13}$ C (\%o) & $\begin{array}{l}\text { Cal. age } \\
(\mathbf{y r} \text { BP) }\end{array}$ \\
\hline CA03-4 & 90 & 90 & Wood & $2315 \pm 50$ & $-21.5 \pm 1.2$ & UZ-5019/ETH-27774 & $2480-2290$ \\
CA03-2 & 73 & 127 & Wood & $2915 \pm 50$ & $-20.0 \pm 1.2$ & UZ-5017/ETH-27772 & $3220-2920$ \\
CA03-2 & 88 & 178.5 & Wood & $3880 \pm 55$ & $-25.0 \pm 1.2$ & UZ-5018/ETH-27773 & $4440-4140$ \\
CA04-1 2A & 26 & 319.5 & Needles & $5525 \pm 60$ & $-27.0 \pm 1.2$ & ETH-29991 & $6440-6200$ \\
CA04-1 2A & 65 & 358.5 & Wood & $6600 \pm 60$ & $-25.6 \pm 1.2$ & ETH-29992 & $7580-7420$ \\
CA04-1 2A & $85-88$ & 380 & Leaf & $8165 \pm 65$ & $-24.7 \pm 1.2$ & ETH-29993 & $9310-8990$ \\
CA04-1 2A & $94-95$ & 388 & Leaves, needles, seeds & $8540 \pm 65$ & $-26.6 \pm 1.2$ & ETH-29994 & $9660-9430$ \\
GR05-3B & $46.5-49.5$ & 618.5 & Wood, leaves & $7900 \pm 120^{*}$ & $-19.7 \pm 1.2$ & ETH-30638 & $9050-8400$ \\
GR05-3C & 20 & 660 & Wood & $8320 \pm 65$ & $-21.5 \pm 1.2$ & ETH-30637 & $9480-9120$ \\
\hline
\end{tabular}

* Larger error due to the small sample size $(<0.5 \mathrm{mg}$ of $\mathrm{C}$, regular sample size $1-2 \mathrm{mg}$ of $\mathrm{C})$.

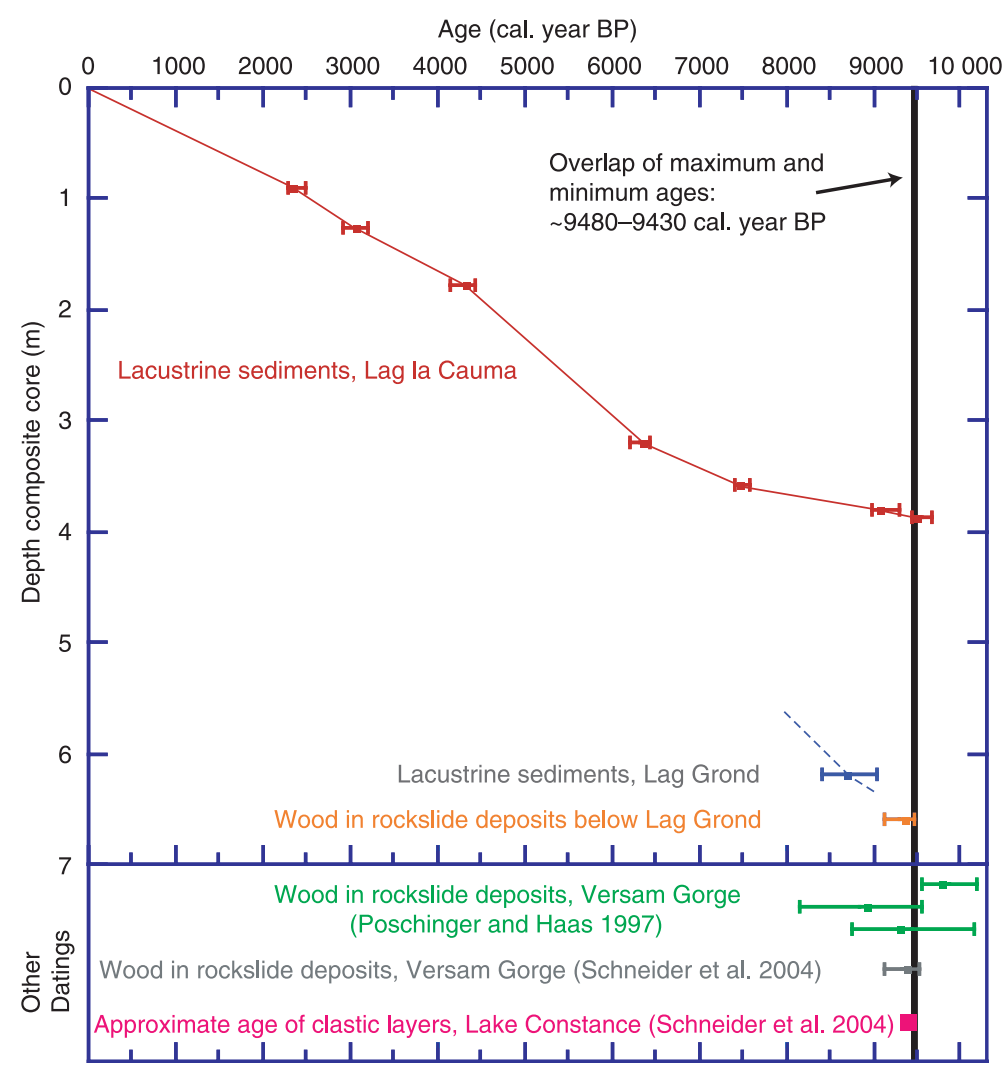

Fig. 5 Comparison of calibrated ${ }^{14} \mathrm{C}$ ages from Lag la Cauma and Lag Grond sediments with different published dates concerning the age of the Flims rockslide. All ages with error bars have been calibrated with OxCal. v3.10 with a $2 \sigma$ range. The square within the error bars shows the mean value of the $1 \sigma$ range. The vertical black line represents the overlap of minimum and maximum ages of the data from this study. This age range agrees well with previously published data and approximates the age of the rockslide.

Holocene timing of the event is supported by the lack of typical glacial, organic carbon-poor deposits in both lakes, which would be expected if the lakes had developed during the Late Glacial.

\section{Implications and conclusions}

Despite the similar slide-related sedimentation history of the two lakes, Lag la Cauma and Lag Grond evolved differently during the early phase. The organic carbon-rich sedimentation in Lag la Cauma initiated shortly after the rockslide, as indicated by the immediate deposition of dark sediments on the hard substrate of the rock slide mass. In contrast, the sediments of Lag Grond deposited during the first phase after the rockslide were dominated by limestone clasts found in the graded sequences in the lower part of the section. This provides strong evidence of an increased mass transport activity following the rockslide mobilizing large masses of fineto coarse-grained carbonate debris. The first strong precipitation events easily remobilized these components and deposited them with turbidity currents in the lake basin. Such layers are absent in Lag la Cauma, which has a much smaller catchment than the Lag Grond. Around Lag Grond, the period of rockslide mass resedimentation lasted several hundred years, which is indicated by the age of the faintly laminated section deposited between the graded sequences. This layer is several hundred years younger than the wood deposited in the Flims rockslide debris (Fig. 4). This early phase could be related to the dammed Ilanz Lake that theoretically could have flooded the Lag Grond basin. For the scenario that the faintly laminated section was deposited in the much larger Ilanz Lake, its lake level must have lasted for several centuries above an altitude of $1020 \mathrm{~m}$ a.s.l. This contradicts both Schneider et al. (2004), who postulated a rapid draining of the lake resulting in a largescale flood in the Rhine river, and Poschinger (2005), who stated that lake level of the Ilanz Lake presumably was never above $936 \mathrm{~m}$ a.s.1. In 
any case, the cored peculiar faintly laminated section postdating the rockslide and predating the onset of the typical Lag Grond-type sedimentation requires some change in physicalchemical lake conditions, which could also be the result of a locally dammed lake that does not require expansion of the Ilanz Lake to that elevation.

The postulated age of the Flims rockslide in the time window from 9480 to 9430 cal. yr BP matches and refines previously published ages (Poschinger and Haas, 1997; Schneider et al., 2004; Fig. 5). This early Holocene age implies that no glacier advanced over the Flims rockslide deposits, and that any glacial sediments found on top of the rockslide mass (Abele, 1974) must have been transported with the rockslide (Poschinger and Haas, 1997) or must be of a different origin. Moreover, new explanations are necessary for the cause and trigger of the Flims rockslide. A direct glacial influence can be excluded (Poschinger, 2002), making the concept of destabilized slopes due to glacial rebound for this largest of the Alpine rockslides no longer an option. According to the new dates, the Flims rockslide occurred during the Mid-Boreal, a period with a high frequency of large mass movements in the Alps. For example, the landslide of Köfels, the largest landslide in the crystalline Alps of Austria ( 2500 mio $\mathrm{m}^{3}$ ), was dated at $9750 \pm 100$ cal. yr BP $\left({ }^{14} \mathrm{C}\right.$ on buried wood; Ivy-Ochs et al., 1998). Another powerful landslide of the Kander Valley ( $\sim 800$ mio $\mathrm{m}^{3}$ ) in the Bernese Alps occurred between 10950 and 8950 cal. yr. BP, most probably around $9550 \mathrm{cal}$. yr BP (Tinner et al., 2005). Such an increased occurrence of large slides in the Early Holocene coincided with a maximum of summer insolation between 11500 and 8500 cal. yr. BP resulting mainly in temperatures characterized by stronger seasonality, increased precipitation in areas where coastal moisture predominates, and reduced precipitation in far inland areas (Kutzbach and Webb, 1993). The increased summer temperatures potentially destabilized permafrost regions, having a negative impact on slope stabilities, as does increased precipitation (Corsini et al., 2001; Tinner et al., 2005). Considering higher-frequency climate changes, the proposed Mid-Boreal age of the Flimser rockslide coincides approximately with a switch from an Early Boreal warm phase to a Late Boreal cold and humid phase (Haas et al., 1998; Tinner and Kaltenrieder, 2005). In any case, the Mid-Boreal increase in large Alpine rockslides occurred in a period with generally higher seasonality (warmer summers and colder winters) that was punctuated with shorter-lived cold and humid phases.

\section{Acknowledgements}

We wish to thank those who assisted us during the various phases of field work and laboratory studies, especially Stefano Bernasconi for his laboratory support and Georges Bonani for conducting the ${ }^{14} \mathrm{C}$ analyses. The authors are grateful to Robert Hofmann for his essential technical help and the communal authorities of Laax and Flims, especially Toni Cadruvi, for their logistical support during the field work. The stimulating input from Kurosch Thuro, Michael Strasser, Emmanuel Chapron and Judith McKenzie are sincerely acknowledged. The comments of three anonymous reviewers improved the manuscript. We acknowledge support of Swiss National Science Foundation.

\section{References}

Abele, G., 1974. Bergstürze in den Alpen: ihre Verbreitung, Morphologie und Folgeerscheinungen. Wiss. Alpenvereinsh., 25, 130.

Abele, G., 1997. Rockslide movement supported by the mobilization of groundwater-saturated valley floor sediments. Zeitschr.f. Geomorphologie, N.F., 41, 1-20.

Blair, R.W., 1994. Moraine and valley wall collapse due to rapid deglaciation in Mount Cook National Park, New Zealand. Mt. Res. Dev., 14, 347-358.

Bonani, G., Beer, J., Hofmann, H., Synal, H.A., Suter, M., Wölfli, W., Pfleiderer, C., Junghans, C. and Münnich, K.O., 1987. Fractionation, precision and accuracy in ${ }^{14} \mathrm{C}$ and ${ }^{13} \mathrm{C}$ measurements. Nucl. Instrum. Methods Phys. Res. Section B, 29, 87-90.

Bonanomi, Y.P., Müller, E.R., Nabholz, W.K. and Scheiwiller, H., 1994. Zur Hydrogeologie des Bergsturzgebietes im Raum Flims. Geologische Berichte, Landeshydrologie und-geologie, $38 \mathrm{pp}$. Bern. Bonnard, Ch., 2004. The meaning of risk assessment related to large landslides. In: Identification and Mitigation of Large Landslide Risks in Europe: Advances in Risk Assessment (Ch. Bonnard,
F. Forlati and C. Scavia, eds), pp. 7-12. Balkema Publishers, Leiden.

Bronk Ramsey, C., 1995. Radiocarbon calibration and analysis of stratigraphy: The OxCal program. Radiocarbon, 37, 425-430.

Bronk Ramsey, C., 1998. Probability and dating. Radiocarbon, 40, 461-474.

Bronk Ramsey, C., 2001. Development of the radiocarbon program OxCal. Radiocarbon, 43, 355-363.

Corsini, A., Marchetti, M. and Soldati, M., 2001. Holocene slope dynamics in the area of Corvara in Badia (Dolomites, Italy): chronology and paleoclimatic significance of some landslides. Geografia Fisica e Dinamica Quaternaria, 24, 127-139.

Crozier, M.J. and Glade, T., 2005. Landslide hazard and risk: issues, concepts and approach. In: Landslide Hazard and Risk (T. Glade, M. Anderson and M.J. Crozier, eds), pp. 1-40. Wiley, Chichester.

Erismann, T.H. and Abele, G., 2001. Dynamics of Rockslides and Rockfalls. Springer, Berlin, 316 pp.

Haas, J.N., Richoz, I., Tinner, W. and Wick, L., 1998. Synchronous Holocene climatic oscillations recorded on the Swiss Plateau and at timberline in the Alps. Holocene, 8, 301-309.

Hajdas, I., Bonani, G., Thut, J., Leone, G., Pfenninger, R. and Maden, C., 2004. A report on sample preparation at the ETH/PSI AMS facility in Zürich. Nucl. Instrum. Methods Phys. Res. B, 223-224, 267-271.

Heim, A., 1932. Bergsturz und Menschenleben. Beibl. zur Vjschr. d. Naturforsch. Ges, Zürich, $218 \mathrm{pp}$.

Ivy-Ochs, S., Heuberger, H., Kubik, P.W., Kerschner, H., Bonani, G., Frank, M. and Schlüchter, C., 1998. The age of the Köfels event - relative, ${ }^{14} \mathrm{C}$ and cosmogenic isotope dating of an early Holocene landslide in the Central Alps (Tyrol, Austria). Z. Gletscherkd. Glazialgeol., 34, 57-68.

Ivy-Ochs, S., Poschinger, A.V., Synal, H.-A. and Maisch, M. The surface exposure age of the Flims landslide. Geomorphology (in press).

Kutzbach, J.E., and Webb, T., III, 1993. Conceptual basis for understanding lateQuaternary climates. In: Global Climates since the Last Glacial Maximum (H.E. Wright Jr, J.E. Kutzbach, T. Webb III, W.F. Ruddiman, F.A. Street-Perrott and P.J. Bartlein, eds), 5-11. University of Minnesota Press, Minneapolis, MN.

Nabholz, W., 1987. Der späteiszeitliche Untergrund von Flims, Mitt. d. Naturforschenden Ges. Luzern, 29, 273-289.

Pollet, N. and Schneider, J.-L., 2004 Dynamic disintegration processes accompanying transport of the Holocene 
Flims sturzstrom (Swiss Alps). Earth Planet. Sci. Lett., 221, 433-448.

Pollet, N., Cojean, R., Couture, R., Schneider, J.-L., Strom, A.L., Voirin, C. and Wassmer, P., 2005. A slab-on-slab model for the Flims rockslide (Swiss Alps). Can. Geotech. J., 42, 587-600.

Poschinger, A.v., 2002. Large rockslides in the Alps: a commentary on the contribution of G. Abele (1937-1994) and a review of some recent developments. In: Catastrophic Landslides: Effects, Occurrence, and Mechanisms ( S.G. Evans and J.V. DeGraff, eds). Geol. Soc. of Am., Reviews in Engineering Geology, 15, 237255.

Poschinger, A.v., 2005. Der Flimser Bergsturz als Staudamm. Bull. Angew. Geol., 10, 33-47.

Poschinger, A.v. and Haas, U., 1997. Der Flimser Bergsturz, doch ein warmzeitliches Ereignis? Bull. Angew. Geol., 2 , 35-46.

Poschinger, A.v., Wassmer, P. and Maisch, M., 2006. The Flims rockslide; History of interpretation and new insights. In: Landslides from Massive Rock Slope Failure (S.G. Evans, G. ScarasciaMugnozza, A. Strom and R.L. Hermans, eds). Nato Science Series, IV, Vol. 49, 347-375, Springer.

Reimer, P.J., Baillie, M.G.L., Bard, E., Bayliss, A., Beck, J.W., Bertrand, C.J.H., Blackwell, P.G. and Buck, C.E., 2004. IntCal04 terrestrial radiocarbon age calibration, 0-26 Cal Kyr BP. Radiocarbon, 46, 1029-1058.

Schmidt, K.-H. and Beyer, I., 2002. Highmagnitude landslide events on a limestone-scarp in central Germany: morphometric characteristics and climatic controls. Geomorphology, 49, 323-342.

Schneider, J.-L., Wassmer, P. and Ledésert, B., 1999. La Fabrique interne des dépots du sturzstrom de Flims (Alpes suisses); caractéristiques et implications sur les mécanismes de transport. C. R. Acad. Sci. Paris, 328, 607-613.

Schneider, J.-L., Pollet, N., Chapron, E., Wessels, M. and Wassmer, P., 2004. Signature of Rhine Valley sturzstrom dam failures in Holocene sediments of Lake Constance, Germany. Sediment. Geol., 169, 75-91.

Schnellmann, M., Anselmetti, F.S., Giardini, D., McKenzie, J.A. and Ward, S.,
2002. Prehistoric earthquake history revealed by lacustrine slump deposits. Geology, 30, 1131-1134.

Stuiver, M. and Polach, H.A., 1977. Reporting of ${ }^{14} \mathrm{C}$ data. Radiocarbon, 19 , 355-363.

Tinner, W. and Kaltenrieder, P., 2005. Rapid responses of high-mountain vegetation to early Holocene environmental changes in the Swiss Alps. J. Ecol., 93, 936-947.

Tinner, W., Kaltenrieder, P., Soom, M., Zwahlen, P., Schmidhalter, M., Boschetti, A. and Schlüchter, C., 2005. Der nacheiszeitliche Bergsturz im Kandertal (Schweiz): Alter und Auswirkungen auf die damalige Umwelt. Eclogae geol. Helv., 98, 83-95.

Wessels, M., 1998. Late-Glacial and postglacial sediments in Lake Constance (Germany) and their palaeolimnological implications. Arch. Hydrobil. Spec. Issues Advanc. Limnol., 53, 411-449.

Received 23 June 2006; revised version accepted 2 May 2007 